\title{
Vulnerability to Environmental Risks and Effects on Community Resilience in Mid-West Nepal and South-East Pakistan
}

\author{
Janpeter Schilling ${ }^{1,2}$, Janani Vivekananda ${ }^{2}$, Moazzam Ali Khan $^{3} \&$ Nisha Pandey ${ }^{4}$ \\ ${ }^{1}$ Institute of Geography, University of Hamburg, Hamburg, Germany \\ ${ }^{2}$ International Alert, London, United Kingdom \\ ${ }^{3}$ Institute of Environmental Studies, University of Karachi, Karachi, Pakistan \\ ${ }^{4}$ International Alert, Kathmandu, Nepal \\ Correspondence: Janpeter Schilling, Institute of Geography, University of Hamburg, Grindelberg 7, Hamburg \\ 20144, Germany. Tel: 44-20-7627-6830. E-mail: janpeter.schilling@zmaw.de
}

Received: May 6, 2013 Accepted: August 6, 2013 Online Published: August 20, 2013

doi:10.5539/enrr.v3n4p27 URL: http://dx.doi.org/10.5539/enrr.v3n4p27

\begin{abstract}
Nepal and Pakistan face a triple challenge of political instability, weak governance and vulnerability to climate change. Communities are highly vulnerable to floods, landslides and droughts. However, the reasons for their vulnerability are complex and differ from location to location. This study has two objectives. First, we analyze and compare the vulnerability of communities to environmental risks in three districts of Nepal with communities in three districts of Pakistan. While we address environmental exposure and sensitivity, the main focus is placed on adaptive capacity including obstacles to adaptation and maladaptation. Second, we explore how the resilience of communities is affected by the combination of environmental risks and weak governance. To identify common and different attributes between and within the two research regions, we apply a comparative conceptual framework to guide the community level case study research conducted in 2011 and 2012 in the Banke, Dang and Rolpa districts of Nepal, and the Badin, Karachi and Thatta districts of Pakistan. We interviewed a total of 288 respondents, including community members and key informants. Our findings suggest that poor governance is a central obstacle to adaptation in both countries but driven by different factors. Examples of maladaptation to climate change risks include provision of rice which undermines the production of traditional crops in Nepal and a water project in Pakistan exposing local communities to floods. The challenge is to improve relations between governance providers and local communities while addressing consequences of environmental risks, including migration and conflict.
\end{abstract}

Keywords: vulnerability, resilience, environmental change, adaptation, conflict, governance, migration, Nepal, Pakistan

\section{Introduction}

Nepal and Pakistan are considered highly vulnerable to climate and environmental change (Allison et al., 2009; Global Adaptation Institute, 2011; Shrestha \& Aryal, 2011; Wheeler, 2011). Vulnerability is most commonly understood as the sum of answers to the following three questions (IPCC, 2007a). What climate changes is the country facing and how strong are these changes (exposure)? How sensitive is the country to these changes (sensitivity)? How capable is the country to deal with these changes (adaptive capacity)? Nepal and Pakistan are exposed to a wide range of environmental risks including floods, storms, droughts, wildfires and earthquakes (CIA, 2013a, 2013b). The recent floods of 2009, 2007 and 2004 each affected several hundreds of thousands of people in Nepal (CRED, 2013). In Pakistan, earthquakes cause the most casualties but floods pose the greater risk as they occur more frequently and affect more people. In August 2011 and August 2012, floods affected more than five million people each. In July 2010, a flood affected more than 20 million people (almost 12\% of the total population) and killed nearly 2,000 (UN, 2011; CRED, 2013). Climate change is likely to increase the frequency and severity of floods and droughts in Nepal and Pakistan (Kripalani, Oh, Kulkarni, Sabade, \& Chaudhari, 2007; Shrestha, Eriksson, Mool, Ghimire, Mishra, \& Khanal, 2010; del Rio, Iqbal, Cano-Ortiz, Herrero, Hassan, \& Penas, 2013). 
Livelihoods in both countries are highly sensitive to climatic changes as agricultural is by far the most important sector, providing $75 \%$ of employment in Nepal and $45 \%$ in Pakistan (CIA, 2013a). The capacityof both countries to adapt to environmental changes is limited by high levels of poverty, weak government and a history of conflict (for a general discussion see Smith, 2004). Nepal is just recovering from a decade of civil war while Pakistan continues to experience internal and external conflicts (Paul, 2005; Sharma, 2006; Nelson, 2012). About a quarter of the 30.4 million people in Nepal live under the international poverty line of $\$ 1.25$ per day (World Bank, 2010). Poverty is lower in Pakistan but the 6th most populated country in the world is on par with Nepal in terms of a very high level of corruption (Transparency International, 2012; CIA, 2013b). While these numbers are useful for an interstate comparison of vulnerability, the actual climatic impacts are experienced at the local level. Several authors have therefore stressed the need to concentrate research efforts at the community level (Adger, 2006; IPCC, 2007a; Schilling, 2012; Schilling, Freier, Hertig, \& Scheffran, 2012). This is precisely what the present article does. First, we analyze and compare the vulnerability of communities to environmental risks in the Banke, Dang and Rolpa districts of Nepal with communities in the Thatta and Badin districts of Pakistan. In Thatta, over 1.2 million acres of land have been eroded or affected by seawater intrusion since the early nineties (DDMA, 2011). Banke, Dang and Rolpa in Nepal were in parts strongly hit by the most recent flood of 2009 (IRIN, 2009; UNFCO, 2011). The second objective of this paper is to show how environmental risks affect community well-being. Individuals, households and communities do not face environmental risks such as floods and storms in separation from socio-economic risks such as income declines, but rather have to deal with an interaction of these risks. The general ability to withstand linked physical, social and economic risks, including conflict is commonly summarized under the term resilience (Gallopín, 2006; Duit, Galaz, Eckerberg \& Ebbesson, 2010; Folke, Carpenter, Walker, Scheffer, Chapin, \& Rockstrom, 2010). We therefore explore how environmental risks interact with socio-economic risks to affect the resilience of the communities. To achieve the dual aim of analyzing the vulnerability to risks and to explore their effects on community resilience, we apply a comparative framework based on field research conducted in 2011 and 2012, supplemented by a literature review and analysis of disaster data. The article proceeds as follows. First, we describe our methods while introducing our conceptual framework, the data collection approach as well as the case study area. Second, we present the results of our study along the three vulnerability elements of exposure, sensitivity and in particular adaptation. Then we show the effects of environmental risks on community resilience before we synthesize the results and conclude with a section providing recommendations on how to strengthen the resilience of the studied communities. We find that addressing local level governance challenges such as lack of trust between communities and governance providers is critical for building resilience.

\section{Method}

\subsection{Conceptual Framework}

The conceptual framework for this study is based on a comparative approach aimed at identifying common and different attributes between and within two research regions. This approach has been proven successful in other vulnerability studies (Polsky, Neff, \& Yarnal, 2007; Schilling et al., 2012). For comparative studies, like the present one, it is particularly important to have a clear understanding of the key terms. There is no generally accepted and precise definition of vulnerability (Füssel, 2007). However, the three elements of vulnerability, namely; exposure, sensitivity and adaptive capacity are consistent throughout the literature (Adger, 2006; Smit \& Wandel, 2006; IPCC, 2007a). For each of the three elements, we follow the definition of the Intergovernmental Panel on Climate Change (IPCC). Hence, exposure is the "the rate and magnitude of climate change" (IPCC, 2007b). Sensitivity can be characterized as "the degree to which a system is affected, either adversely or beneficially, by climate variability or change" (IPCC, 2007a). To further specify this broad definition, we focus on the resource dimension of sensitivity as suggested by Barnett and Adger (2007). The resource dimension can be understood as a function of the reliable availability of the affected resources (prior to the climate stimuli) and the importance of the resource for the communities. Climate change exposure (e.g. temperature rise, changes in rainfall) always affects local communities through environmental changes (e.g. decrease in water availability). And while not all environmental changes (e.g. deforestation) are related to climatic changes, we use both terms synonymously, as we mostly focus on exposure to climate-related risks such as storms, floods, landslides, droughts, temperature extremes and changing rainfall patterns. Adaptive capacity is "the ability or potential of a system to respond successfully to climate variability and change" (IPCC, 2007a). In contrast to exposure and sensitivity, the adaptive capacity is determined by socio-economic factors, ranging from 
education, income and health, to institutions, knowledge and technology (IPCC, 2007a).

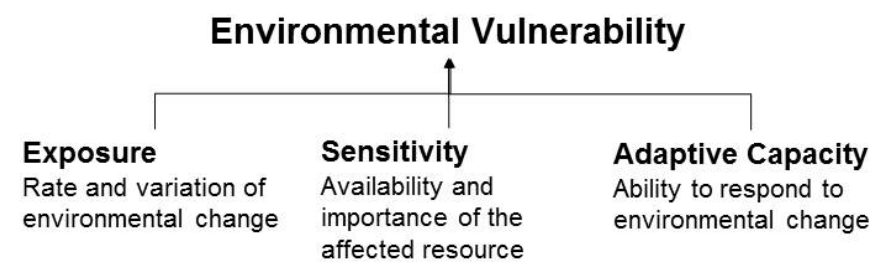

Figure 1. Environmental vulnerability (adopted from IPCC, 2007a)

For the vulnerability analysis (first aim of the paper), we use the IPCC-based framework shown in Figure 1. We place the focus on adaptive capacity because this is the first necessary step required to understand the ability of communities to adapt to environmental risks. It is important to stress that the adaptive capacity can not only be used for adaptation that reduces vulnerability to environmental change but also for maladaptation which is intended to reduce vulnerability but actually does the opposite (Barnett \& O'Neill, 2010). We therefore analyze the positive utilization of the adaptive capacity as well as its negative implications.

To explore the effects of the environmental risks on the communities (second aim of the paper), we focus on resilience which can be defined as "the ability of countries, communities and households to anticipate, adapt to and/or recover from the effects of potentially hazardous occurrences (natural disasters, economic instability, conflict) in a manner that protects livelihoods, accelerates and sustains recovery, and supports economic and social development" (Inter-Agency Working Group on Resilience, 2012). We use resilience here because, given the linked ways in which risks are experienced at the household level, we are not only interested in the communities' ability to adapt to specific environmental risk (the adaptive capacity), but rather the generalability to withstand a combination of environmental and socio-economic risks (Gallopín, 2006; Folke et al., 2010). The concept of resilience originates from ecology but it is increasingly being applied to environment-human interactions and risks (Folke, 2006; IPCC, 2007a). Risk, as Scheffran et al. (2012) point out, is commonly understood as a product of the likelihood of an event to happen and its (potential) impact. A relevant socio-economic risk in this study is conflict which is a situation that occurs when two or more parties believe that their interests are incompatible, express hostile attitudes or take actions that damage the other's ability to pursue its interests (Scheffran et al., 2012).

\subsection{Data Collection}

The main data collection method was qualitative field research conducted between November 2011 and January 2012 in Nepal and between December 2011 and March 2012 in Pakistan. The research consisted of key informant interviews and focus group discussions. Individuals were interviewed using a semi-structured questionnaire geared to explore the research objectives while leaving room for interviewees to comment on other topics they considered relevant for their livelihood. The key informant interviews were used to collect information from significant community members such as village elders and community mobilisers and key stakeholders within the local administration, experts within development agencies and institutions. Someone was considered a key informant when he or she had a record of theoretical knowledge or extended practical experience of environmental vulnerability in the region, for example, representatives of local women's and natural resource user groups, members of local businesses and ministries, local journalists as well as representatives of national and international non-governmental organizations (NGOs). All key informant interviews were based on common research principals (see Patton, 2005; Bogner, Littig, \& Menz, 2009). For instance, interviews were always conducted by at least two interviewers to maximize objectivity. The focus group discussions were held to combine different perspectives on the same issue. This approach was helpful to understand the complexity and multiple facets of the subject matter. Focus group discussions were conducted in situ in each location and consisted of a minimum of eight and a maximum of twenty-five community participants. Groups included male and female residents, youth and the elderly, among them beneficiaries of local development projects. Overall, the comparative framework based on qualitative research methods, supplemented by secondary data analysis and literature review was suitable to address the research objective. The interviews and focus group discussions gave different groups the possibility "to tell their story" and hence enabled us to identify different perspectives, perceptions and varying experiences of stakeholders to grasp the complexity of 
the subject matter. However, the study also has limitations. Whilst all information included was triangulated with desk research and at least two additional interviews, it was not always possible to validate all points made by the interviewees. Furthermore, our sample size is small compared to the total populations of each district. Hence, any conclusions drawn from this study are location specific and cannot be generalized for the entire district or country. Instead, the case studies are designed to identify different factors of vulnerability and effects which inform studies in other locations and larger scales.

\subsection{Study Area}

In Nepal, the research was carried out at the Village District Committee (VDC) level in the districts Banke, Dang and Rolpa (Figure 2). The three districts, all part of the Mid-western administrative region, were chosen to compare locations with different levels of environmental vulnerability. The vulnerability mapping conducted for Nepal's National Adaptation Programme of Action (NAPA) ranks all 75 districts according to various vulnerability indices, including exposure and adaptive capacity (Ministry of Environment, 2010) (Note 1). Rolpa consistently ranks within the lowest two quintiles for all vulnerability indices, whereas, on average, Dang and Banke rank within the second and third quintiles of vulnerability. The three districts also represent different topological characteristics with Dang being a valley, Banke characterized by plains and Rolpa's landscape being dominated by hills (UNFCO, 2011).

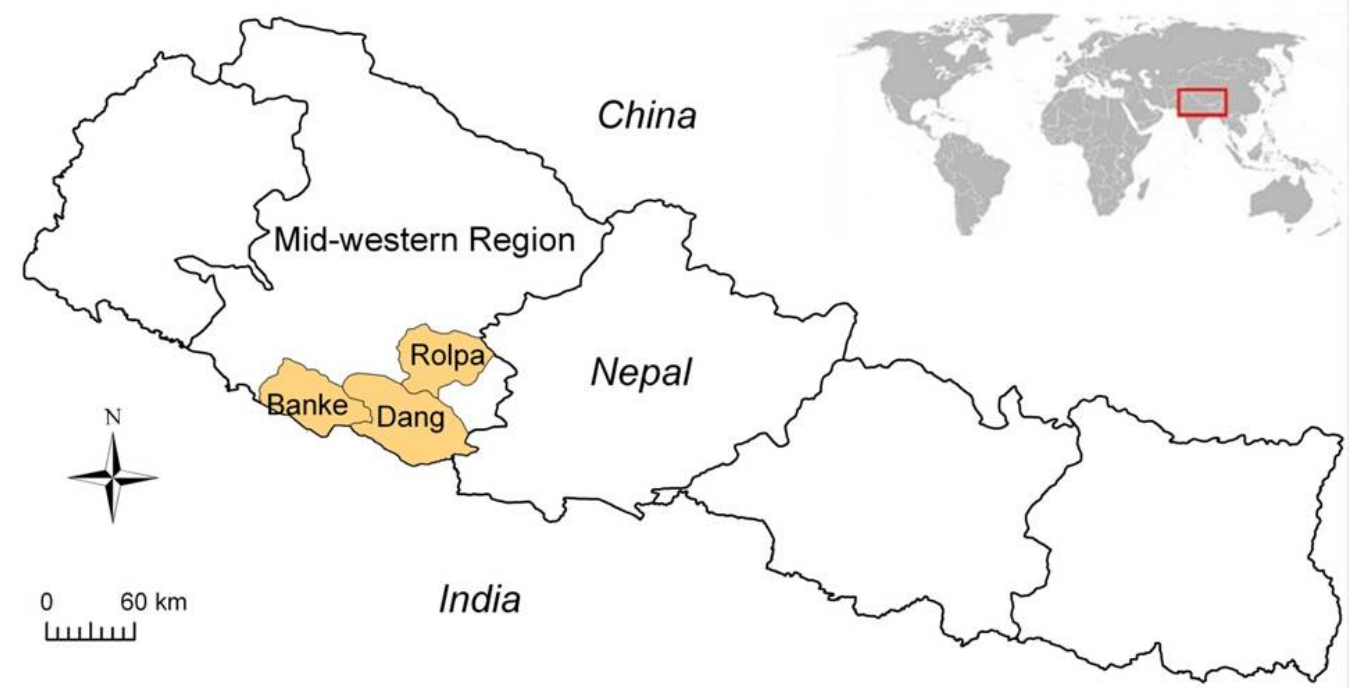

Figure 2. Research districts in Nepal (the authors)

Dang borders the Indian state of Uttar Pradesh and is characterized by valleys and plains. The district is highly diverse in terms of ethnicity and caste. The majority ethnic group is the Tharu, and the major powerholders are the Bahun and Chhetri castes. Dang benefits from the main east-west highway running through the district which enables trade with the rest of the country.

Banke, in the Terai region, is home to the regional headquarters of Nepalgunj, which is the base location for the majority of international institutions and development agencies working in the Mid-western region. As such, despite being less vulnerable to climate and environmental impacts, Nepalgunj in particular and Banke in general enjoy greater service provision than the other two study districts in Nepal (Ministry of Environment, 2010). The district is relatively food secure, with widespread irrigated paddy cultivation. However, the border regions are characterized by higher than average rates of criminality and ethnic divisions (Miklian, 2008).

Rolpa, by contrast, is a remote hill district. Its isolated position and poor road network is one of the reasons why it is underdeveloped, even by Nepali standards. The district, a former "flashpoint" (UNFCO, 2011:3) in Nepal's civil war, is still highly food insecure. Divisions between the Pahadi, Bahun and Chhetris, as well as other groups such as the Magar Kham, can still be seen in the allocation of fertile land and access to water.

We conducted interviews with 18 key informants and five focus group discussions with 72 respondents in the villages Khajuraha (Banke district), Gadhawa, Rampur and Narti (Dang) and Whama (Rolpa). To set the local within the national perspective, we interviewed 14 key informants in Kathmandu. 


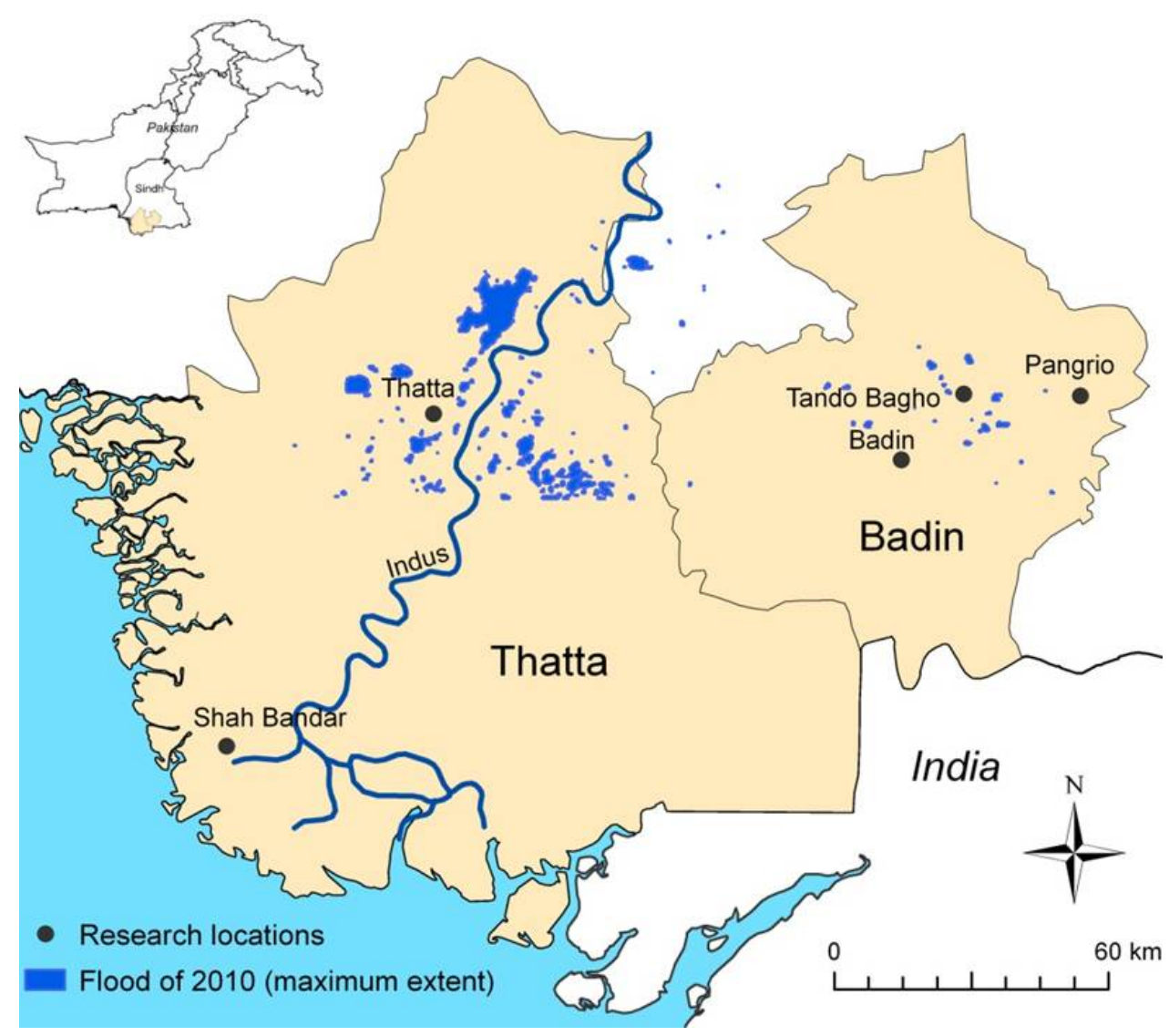

Figure 3. Main research locations and maximum extent of 2010 flood in Pakistan (the authors based on UNOSAT, 2010)

In Pakistan, the field research was mainly carried out in and around Thatta and Shah Bandar (Thatta district) and in Badin, Tando Bagho and Pangrio of the Badin district (Figure 3). Fewer interviews were conducted in Chor Jamali (Karachi district). We interviewed 168 local key informants and community members in semi-structured interviews and focus group discussions. Additionally, 16 key informants were interviewed in Islamabad. The districts of Karachi, Thatta and Badin are all part of Singh which is the second largest province in terms of population (National Institute of Population Studies, 2008). The poverty rate in Sindh is 36\%, above the average in Pakistan of 32\% (World Bank, 2013). Sindh is one of the most multi-ethnic provinces and its capital, Karachi, has a history of ethnic and sectarian violence (e.g. Nelson, 2012). Ethnic polarization in Sindh is considered serious because of the presence of large ethnic groups and their clash of interests. For instance, tensions exist between Mohajirs and Sindhis, who make up the majority of community respondents for this study. Mohajirs are an Urdu speaking community, who migrated from India during partition and over time have dominated business and politics. Sindhis felt threatened by the growing influence and success of the Mohajirs, who were seen as a non-assimilationist, urban and privileged minority in Sindh (Feyyaz, 2011). There are also numerous tribal groups in Sindh. The major tribes of the study area include Baloch, Khaskheli, Mallah, Mir Bahar, Megwar, Kohli, Sodai, Machhi, Sathia, Hangoro, Kathiar, Syeds, Qureshi, Samo, Jokhio, Mirani, Jat, Multani, Panjabi and Pathan.

The Thatta district covers over 17,355 square kilometers of the Sindh province. The district's population is about 1.8 million (UNOCHA, 2010). The district administration was, until recently, governed by the local government system. Thatta was selected as a study site because of its coastal location and exposure and sensitivity to environmental risks, namely coastal intrusion and the floods in 2010 and 2011.

Badin district has a size of 6,726 square kilometers and a population of about 1.6 million people. The majority of the district's population lives in rural areas (Government of Sindh, 2008). The environmental risks in Badin are predominantly linked to extreme and unpredictable rainfall patterns, storm surges and cyclones. 


\section{Results}

The results are divided into one section on vulnerability and one on the effects of environmental change on community resilience. In the vulnerability section, exposure and sensitivity are grouped, as the focus is placed on adaptation.

\subsection{Vulnerability}

In each section, the results of the study will be presented first and then contrasted with the results of the secondary data analysis and literature review. The secondary sources are especially important for the discussion of exposure and sensitivity as official institutions are a better source for climate data than community members.

\subsubsection{Exposure and Sensitivity}

Table 1 shows major environmental risks as perceived by the respondents of the focus group discussions and interviews in Nepal and Pakistan. In Rolpa, drought and landslides were named most often while respondents in Banke and Dang mentioned floods most often. The floods and landslides were mostly associated with the excessive rainfall during the monsoons. In addition, forest fires were mentioned to occur during the dry season and winter drought. Despite the locational differences of environmental risks, communities in all three Nepalese districts reported having trouble to cope with an increased unpredictability of the risks. The uncertainty is manifested in monsoons lasting several months in one year and only a few weeks the following year. In addition to the increase in interannual rainfall variability, higher extreme temperatures were reported for the summer months. One respondent from a forestry program in Dang commented that, in 2012, farmers had to deal with the "changes in seasons". Rainfall did not come on time and temperatures were very high in the summer. According to two farmers and several local residents, Dang has experienced floods and landslides every year since 2007 as well as an increased incidence of forest fires more recently. Difficulties were mentioned in planning around this uncertainty. One respondent outlined: "there was no rainfall this year and for the past 25 years the yield has been down."Farmers stated that they have had to use different drought resistant crops under the new agricultural policy. However, faced with the recent variability, these new seeds have failed. A representative of a local NGO stated: "a life dependent on farming cannot be sustained if this kind of rainfall continues."

In Pakistan, the major environmental risks reported in both districts were floods, storms and droughts. Farmers and other community members associated the drought with the emergence of deadly diseases, malnourishment, school drop-outs and forced migration of people. The Sindh province historically has a cycle of drought and heavy rain of 200 millimeters every four years according to unpublished records of the Pakistan Meteorological Department. The worst drought, lasting from 1997 to 2000, caused severe agricultural losses as reported by key informants and community members. Further respondents reported problems of sea water intrusion, loss of pastures, and depletion and deterioration of groundwater reservoirs. According to key informants from the Irrigation Department, agricultural production in Sindh has been affected by a lack of irrigation infrastructure, shortage of fresh water, decreasing arable land, water logging, and salinity which resulted in low yields. Overall, Table 1 illustrates that most research regions in both countries are exposed to multiple environmental risks. Floods were a risk in four out of five locations.

Table 1. Major environmental risks identified by respondents in Nepal and Pakistan (the authors)

\begin{tabular}{lccccc}
\hline & \multicolumn{3}{c}{ Nepal } & \multicolumn{2}{c}{ Pakistan } \\
\hline & Rolpa & Banke & Dang & Thatta & Badin \\
Floods & & $\mathrm{x}$ & $\mathrm{x}$ & $\mathrm{x}$ & $\mathrm{x}$ \\
Storms & & & & $\mathrm{x}$ & $\mathrm{x}$ \\
Drought & $\mathrm{x}$ & & $\mathrm{x}$ & $\mathrm{x}$ \\
Landslides & $\mathrm{x}$ & & & & \\
\hline
\end{tabular}

This perception is in line with official national data, recorded by the Centre for Research on the Epidemiology of Disasters (CRED). Table 2 shows that floods were the major environmental risk in Nepal and Pakistan in the recent past. (Note 2) Most of the recorded disasters were floods affecting by far the highest number of people. 
Table 2. Number and type of top ten disasters in Nepal and Pakistan between 1994 and 2013 (CRED, 2013)

\begin{tabular}{lll}
\hline & Nepal & Pakistan \\
\hline Number of floods & 5 & 7 \\
Total number affected by floods & $2,029,892$ & $41,631,288$ \\
Number of earthquakes & 1 & 1 \\
Total number affected by earthquakes & 167,949 & $5,128,309$ \\
Number of droughts & 1 & 1 \\
Total number affected by droughts & 200,000 & $2,200,000$ \\
Number of storms & 0 & 1 \\
Total number affected by storms & 0 & $1,650,000$ \\
Number of mass movements wet & 2 & 0 \\
Total number affected by mass movement wet & 345,865 & 0 \\
\hline
\end{tabular}

Subnational data for Nepal supports the findings of the qualitative research. Table 3 shows that since 1990, floods have been most harmful to human wellbeing in Banke and Dang while in Rolpa landslides have been most destructive.

Table 3. Floods and landslides in Banke, Dang and Rolpa districts of Nepal between 1990 and 2011 (CRED, 2013)

\begin{tabular}{llll}
\hline & Banke & Dang & Rolpa \\
\hline Floods & 30 & 43 & 5 \\
Total number & 8 & 24 & 7 \\
Total number of people killed & 571 & 400 & 17 \\
Total number of houses destroyed & & & \\
Landslides & 6 & 18 & 22 \\
Total number & 4 & 5 & 15 \\
Total number of people killed & 29 & 22 & 58 \\
Total numberof houses destroyed & &
\end{tabular}

Further, the observations from the ground match findings from the scientific literature pointing to changes in the annual rainfall cycle, increases in heavy rainfall events and longer droughts (Kripalani et al., 2007; Kale, 2012; Pradhan et al., 2013). For instance, the number of days with 100 millimeters of rainfall is increasing. The timing and duration of rainfall is changing. As glaciers recede from rapid snow and ice melting, glacier lakes are expanding (Shrestha et al., 2010; Wu, Yao, Huang, Z. Liu, \& G. Liu, 2012). The government of Nepal notes that climate change has adverse impacts on "agriculture and food security, water resources, forests and biodiversity, health, tourism and infrastructure" (Government of Nepal, 2011).

In 2009, Rolpa experienced both severe drought and excessive rainfall (WFP, 2010a). The 2009 monsoon experienced a significant delay. Irrigation facilities are available in only about one third of the cultivated area. Rain-fed irrigation is the only alternative source of water for summer crops. The late start of the monsoon affected the paddy crop adversely: paddy plantation occurred in only 95\% of the area (WFP, 2010b). Farmers had to plant mature seedlings excessively, especially in the hills and mountains. This resulted in low paddy productivity (WFP, 2010a).

In the Sindh province of Pakistan, the two types of floods - riverine and torrential floods - mostly occur during the monsoons between July and August (Beg, 2012). Riverine floods are often predictable and therefore responses can be planned, whereas torrential floods are more sudden, intense but less frequent. The catchment area of these floods is in Balochistan, which is connected to Sindh through the Khirthar range. In July 2010, Balochistan experienced heavy rainfall and floods hit the eastern boarder of Sindh, causing extensive damage and affecting approximately 1.4 million people (Figure 3 ). The flood destroyed the flood protection network of the Right Bank Outfall Drain (RBOD) and the main Nara Valley drain canal (Memon \& Thapa, 2011). In July 2011, Pakistan experienced below normal monsoon rains. However, in 
August and September, a strong weather system entered the area of Sindh from the Indian states of Rajasthan and Gujarat, gaining strength and causing heavy downpours in the southern part of the country. The four weeks of continuous rain created an unprecedented flood situation in Sindh.

On average, two to three storms form in the Arabian Sea per calendar year, one in the pre-monsoon period from May to June, and one to two in the post-monsoon period from August to December (Evan \& Camargo, 2011). The cyclones generated in the Arabian Sea normally move in the westnorth-westerly direction. And while the depths of the ocean basins near Pakistan avoid huge storm surges and the frequency of storms along the coast of Pakistan is fairly low, the storms cause significant damage when they occur (Government of Pakistan, 2007; Siddiqui, 2009). One of the highest storm surges of $3.4 \mathrm{~m}$ was recorded on 12 May 1999 when a storm hit Thatta and Badin after making landfall at southeast Sindh. The storm caused about 700 casualties and a total damage of about 6 million USD (Sarfaraz \& Dube, 2012). In June 2007, the storms Gonu and Yemyin hit the Balochistan coast while devastating effects were recorded all along the Sindh coast (Wang, Ding, Fu, Kang, Jin, Shukla \& Doblas-Reyes, 2005; Galvin, 2007). In June 2010, the tropical cyclone Phet generated a surge of $1.17 \mathrm{~m}$, brought significant rainfall to the Balochistan and killed 15 people in Pakistan (Sarfaraz et al., 2012).

Both Nepal and Pakistan are highly sensitive to the described climate exposure. Mostly rainfed agriculture is very important for the countries in terms of employment and gross domestic product (CIA, 2013b, 2013a). In all VDCs visited in Nepal, agriculture was the predominant source of livelihood. In Dang, poor soil quality and dependence on seasonal river flow increase the district's sensitivity. Rolpa dependents on the Mardi Khola stream for irrigation.

Agriculture in Sindh has become less important in terms of gross provincial product. In 2008, agriculture contributed about $15 \%$. However, more than two thirds of the population in Sindh still work in agriculture (Arby \& Rasheed, 2010). The major products are rice, sugarcane, cotton and wheat, along with marine fish and livestock (Beg, 2012).

\subsubsection{Adaptation}

There is no universally accepted catalogue of what constitutes adaptation or adaptive capacity. As stated in the method section, the IPCC (2007a) suggests including education, income, health, institutions, knowledge and technology. The following sections make reference to these factors, identifying governance and institutions as the key determinant of adaptive capacity in each study site. The analysis is structured along obstacles to adaptation, adaptation measures, and maladaptation.

\subsubsection{Obstacles to Adaptation}

Based on the qualitative research and supplemented by literature review, we identified the following three central obstacles to adaptation, (1) poor governance, (2) limited foresight, partially related to past conflicts, and (3) lack of jobs, education and infrastructure.

An indication of poor governance in Nepal was the local perception of being disconnected from the national government and political process. The majority of community respondents expressed apathy towards the government. For example, community members stated that they have been waiting over six years for a new political settlement after the Comprehensive Peace Agreement was signed (Do \& Iyer, 2010). Community frustration with the government was not limited to general political stalemate but it was also expressed with respect to a lack of prioritization of development and climate change responses. These are critical in decreasing environmental risks and community vulnerability. Community members and NGO representatives stated that even when the government and political parties at the national level agree to climate change plans, such as the NAPA, local implementation and service provision was lacking. Frequently, community respondents raised criticisms of local government officials. Corruption and nepotism appeared to be deeply entrenched in almost all of the VDCs we visited. For example, in both Dang and Rolpa, farmers stated that state services such as citizenship, disability certificates and new (hybrid) seeds are granted as favors in return for political affiliation. There was a strong sense that local elites control access to information in order to maintain their positions of power. Local community members stated that local and especially national government officials do not make adequate efforts to consult ordinary villagers about their views and priorities. Local departments of each line ministry are often more accountable to their ministries in Kathmandu than to their local communities, especially since these roles are often unelected political appointments. According to one key informant in Nepalgunj, Banke, "the government should feel they have a responsibility to their people, but at local level they are not elected so there is no accountability to citizens". Respondents outlined that they have yet to feel the government's 
presence at the village level and at times feel that the presence is limited to the district headquarters. In Dang, VDC leaders, who should be immersed in local village dynamics, were found to be living in the district capital, which in many cases is several hours of a walk away from their villages. To these people, travelling to meet local government officials at headquarters can be costly and time-consuming. In one village in Rolpa, where most men had migrated for work, the women said that since they received adequate remittances, they did not bother taking part in local political consultations and forums as it was not worth their while. Rather than viewing political participation as a means of empowerment, they viewed it as a waste of their time, judging that they would be more resilient if they stayed working in their village and relied on remittances rather than lobbying for political resources.

In Pakistan, two major indications for poor governance were found. First, discontent with government action related to an infrastructure project (discussed under maladaptation) and second, biased distribution and control of land rights. Local communities depend on land controlled by landlords (called Vadairas) and the Members of Provincial Assembly (MPA). For example, in Thatta, Vadairas and MPAs own the majority of land. Households living or working on that land strongly dependent on the landlord. As a result, local people are reluctant to question, challenge or demand rights from their landlords. Respondents explained that during election time, the government distributes government land (often barren, unproductive land or flood plains, which are vital buffers against coastal intrusion) to the local community. The Vadaira then chooses who receives plots. This is done in a biased manner as a number of respondents reported. According to a local religious elder (a Hafiz), the situation of landownership undermines the adaptive capacity of the communities because marginalized communities do not speak out against their landlords over resource allocation in fear of losing their homes and their livelihood. This trend of acceptance of elite power in terms of land is also reflected in the justice system. When people have disputes, they prefer to go to their landlords rather than the court of justice, as going over the landlords' heads would be perceived as disrespectful.

Limited foresight was identified as the second obstacle to adaptation. In Nepal, many respondents within farming communities explained that they were not planning for the long-term future as they no longer saw the value of it. Older respondents explained that this was due to the legacy of Nepal's decade-long civil conflict. During the war, there were high levels of uncertainty about what was going to happen. There was little state presence in many places, including Rolpa and much of Banke and Dang. Moreover, security and justice provision was unaccountable and arbitrary. Rights were not secure and basic services such as water for irrigation were not maintained. While people learnt to live without much state intervention, this living was on subsistence, day by day basis. People did not know what the future would hold and as such could not make any decisions about the future. This has meant that now, although the conflict is over, a strong culture of fatalism remains. Many traditional, historical adaptation approaches have fallen out of use and have not been passed on to the next generation, who grew up during the civil war. Furthermore, no new adaptive methods were developed during the conflict period. According to one key informant, this has held back farmers' adaptive capacity in Rolpa by ten years. In Pakistan, we also found indication for limited foresight. For instance, fishermen do not engage in any savings scheme. One fisherman reported "if there is a good catch, then we might earn a big amount, but if the catch is bad, we have nothing". Another one summarized "we don't think about the future, we live in the present".

The third general obstacle to adaptation can be summarized under lack of jobs, education and infrastructure. For example, Dang is strategically located on the main east-west highway. However, the poor quality of the roads and landslides frequently interrupt access to markets. In Pakistan, young people interviewed noted that there are few jobs. A number of respondents reported that jobs were allocated to individuals on the basis of political affiliation and influence, rather than on merit. This has created situations where parents are less interested in educating their children. Furthermore, there was a general perception among the respondents that it is better to only have basic skills and take up small business than to go to school and pursue an education. According to one official in Pakistan, "the problem now is the continued employment of unskilled high level people - political appointments who don't have technical knowledge”.

\subsubsection{Adaptation Measures}

There are several government-led programs to improve the adaptive capacity of communities. In the following we briefly present three adaptation measures that were frequently mentioned by respondents. After a short literature-based background on the Local Governance and Community Development Programme (LGCDP), the Feed the Future program (both Nepal) and the Watan card system in Pakistan, we show how these adaptation measures were received by the communities. 
The aim of the LGCDP, lasting from 2008 to 2012, was to reduce poverty and to strengthen the adaptive capacity of communities through improved access to public goods and services (Government of Nepal, 2006). The access was to be improved through strengthening the capacity and accountability of local governance systems. For instance, "awareness centers" were created, where citizen-elected "community mobiliser" share information about LGCDP decisions and citizens can raise ward level concerns to their local Village Development Officer. While the initiative is a positive step towards decentralization and promoting subsidiarity, our research revealed a number of challenges in its implementation. A major challenge was ensuring that participation in decision making was not captured by existing power holders in the community at the expense of others. Respondents highlighted that under the LGCDP, the same group of people might be involved in multiple committees. In addition, poorer families cannot spare the time to become engaged in participatory consultations, leaving space for the more influential and affluent families to dominate the agenda and set the village priorities.

The Feed the Future program, funded by the US Agency for International Development (USAID) aims to work with the government of Nepal in addressing the country's most pressing food security, poverty and nutrition challenges. Banke, Dang and Rolpa are all selected districts under the program. Measures include efforts to improve education and literacy, value chain enhancement, encouragement of crop rotation to improve nutrient retention and introduction of locally-adapted improved varieties (Government of the United States, 2006). Respondents reported that the hybrid seeds can increase yields in a more variable climate. In Rolpa and Dang however, farmers mentioned that the program would contribute to existing problems of land rights and access to water. They also expressed concerns about cross breeding and use of new seeds from India, to which they attributed the near extinction of local varieties of potato and mustard. Similarly, in the face of new hybrid seeds, old varieties of rice (such as Suraj and Prithvi) were reported to have vanished.

In Pakistan, the government launched a cash transfer scheme based on so called Watan cards to compensate families directly affected by the 2010 floods. The idea was to issue debit cards carrying compensation money, with a future transfer to be made depending on need and criteria (Kurosaki, Khan, Shah \& Tahir, 2012). However, the scheme faces several technical and administrative difficulties on the ground, including delays in getting access to money, monitoring and follow-up problems as a result of black marketing and irregularities in the beneficiaries list. Most importantly is the lack of facilitation, training and information on the scheme. In Sindh, we were informed that in the first year of the scheme, the most vulnerable of the groups (such as female-headed households) were not issued Watan cards as they did not possess an identification (ID) card, which was a requirement. According to a key informant from the donor community, the local government's capacity and problems of communicating information have been the biggest obstacles to the execution of the scheme. Media reports have criticized issues of corruption (Daily Times, 2012; Pakistan Today, 2012). However, positives identified by beneficiaries are that the Watan card has necessitated the need for ID cards, which is a tangible sign of building state-citizen relationships. Nevertheless, community members in Thatta noted that there was some confusion among the villages between the Watan card and other cash transfer schemes run by other development agencies which bypassed the national initiative. This has caused some duplication of resources going to the most politically connected and educated community members, who are informed enough to tap into these resources.

\subsubsection{Maladaptation}

Measures to reduce the vulnerability of communities in the short run, can have the opposite effect in the long run as the following examples of distribution of rice to prevent food crises in Nepal and an infrastructure project in Pakistan show. While the provision of rice stabilizes acute food situations, it undermines food security in the long run by discouraging local farmers to adapt to changing climate and environmental conditions. The provision of rice has also created an appetite and expectation for rice, which led to an increased cultivation of rice in the research regions. However, in contrast to the traditional barley and millet, rice cannot be grown sustainably in the research areas, especially not in mountainous regions. Historically, mountain and hill people would eat a range of cereals and food varieties such as buckwheat and oats, millet and root vegetables, which were more suited to the climate and terrain. However, since the end of the conflict and the provision of rise by the government, there appears to be an emerging hierarchy in food staples. Rice is seen as a top food staple as it is eaten by the wealthy. As one respondent in Rolpa noted, "rice is good enough for the rich in Kathmandu, why isn't it good enough for us?" This demand for rice among the poor was also reported in Banke by key informants working on food security projects. At the time of our research, food aid was being scaled down with a view to ending it in Rolpa. This means that 
local farmers would have to rapidly adjust to having to grow cereals in increasingly unviable or unpredictable climatic conditions. Yet, several key informants, for example from Practical Action, stated that is it highly unlikely, that any political party will ever completely stop rice aid, as this is seen as anti-development and discrimination against the poorest.

In Pakistan, the Left Bank Outfall Drain (LBOD) and Right Bank Outfall Drain (RBOD) show how infrastructure projects geared to improve the local water situation, can increase the exposure of communities to floods. The majority of community respondents in our study identified the LBOD and the RBOD as the most significant cause of their vulnerability to environmental change. This perception was backed by key informants. The LBOD is the largest irrigation project carried out by the government of Pakistan. The project, funded by the World Bank started in 1986 and $85 \%$ of it was completed by 1999. It was designed to collect saline water from the ground and drain it into the Arabian sea (World Bank, 1997). However, respondents have argued that it is doing the opposite, allowing sea water to intrude through canals and affecting groundwater quality as well as causing pollution. The polluted water is then used by communities for agriculture and domestic purposes. In addition, respondents have made the LBOD responsible for aggravating the effects of climatic event. Participants of a focus group discussion in Badin reported that the outfall drains were unable to cope with the extra water from heavy rainfall, leading to devastating floods in 2008 and 2011. According to a respondent from the Irrigation Department: "rainfall is not unprecedented in Sindh and it has been increasing for the past five years, but no plans have been put in place to increase the capacity of the drainage system". Local communities in Badin complained that had the LBOD not existed, cyclone-related losses could have been minimized and groundwater would not get contaminated. Community members involved in this study were highly aware of the observable impacts of the LBOD and RBOD, and were very resentful of this. Many claimed that they are "now against the government", citing the LBOD and RBOD as the main reason. According to an Irrigation Department official, "the whole system [LBOD] was put in place by politically appointed people rather than technical people. In the whole Provincial Department of Irrigation and Power in Sindh, there are only two technical persons and the rest are political appointments of two landlords." The concerns raised by the respondents find support in reports by organizations who have evaluated the project. Based on an assessment report by the Inspection Panel of the World Bank, the government of the United States, for example, concluded that the people in the downstream area "were most exposed to the risks of system failure and exacerbation of natural climatic extremes" (2006). Other reports have linked major technical flaws of LBOD to natural disasters (International Bank for Reconstruction and Development, 2006; Junejo, 2011). The government of Pakistan has informally acknowledged that the RBOD was a failure and suspended funding to the initiative in 2012 (Channa, 2011; Dharejo, 2012). As a result, it has come up with a plan-RBOD-II to divert the contaminated waters of the RBOD to the sea through a new drainage system. However, according to expert respondents, this six-year project has latent flaws-most notably the fact that for a three kilometer stretch, the RBOD-II will share its banks with the Indus River, increasing the chances of the contaminated waters flowing into the Indus (Note 4).

\subsection{Effects of Environmental Change on Community Resilience}

The sum of the communities' climate exposure, sensitivity and adaptive capacity has significant effects on the communities' resilience. Table 4 summarized the major effects as stated by the respondents.

Table 4. Major effects of environmental change on communities in Nepal and Pakistan (the authors)

\begin{tabular}{|c|c|c|}
\hline & Nepal & Pakistan \\
\hline \multicolumn{3}{|l|}{ Migration } \\
\hline Push Factors & $\begin{array}{l}\text { - decreased predictability of rainfall } \\
\text { - } \quad \text { environmental risks } \\
\text { - increasing costs of agricultural production }\end{array}$ & \\
\hline Pull Factors & $\begin{array}{l}\text { - } \quad \text { income opportunities } \\
\text { - } \quad \text { existing networks of relatives in urban areas }\end{array}$ & \\
\hline Conflict & $\begin{array}{l}\text { - over resources in the receiving area of migration } \\
\text { - over water and drilling of boreholes }\end{array}$ & $\begin{array}{l}\text { - } \quad \text { over land resources } \\
\text { - } \\
\text { over fish resources }\end{array}$ \\
\hline
\end{tabular}

In Nepal, increased rainfall variability and hence decreased predictability were the most prominent climate 
and environment related push factors of migration. Farmers reported that they can no longer tell seasons apart or count on the monsoon rain coming at the right time, making it difficult to know when to plant crops. These changes mean that famers face a wider range of problems from increased crop pests, altered cropping cycles and lower viability of certain crops. The environmental risks, specified earlier in Table 1, are a driver of migration as they affect the physical safety of the community members. In addition to the direct effects, for example, being surprised by a flood, respondents named knock-on implications on health, education and especially trade when landslides cut off roads, limiting access to hospitals, schools and markets. While floods and landslides are more likely to lead to permanent migration, hill communities of Dang and especially Rolpa pointed to a trend of increased frequency and duration of seasonal migration. Respondents with migrating family members explained that this is partly because the cost of staying is increasing. Small farmers require high capital investment for modernization of agriculture, for example to bore deeper to reach groundwater. As a result, smallholder farmers are increasingly tempted to use savings to leave rather than to invest. This affects agricultural practice and output. Hill farmers would traditionally migrate to cities during the fallow period between planting and harvesting, but they would return periodically to tend crops and remove weeds before harvest. However, now, because crop yields are becoming more variable, farmers stated that they tend to stay away for longer without tending crops between planting and harvest. The out-migration of predominantly young men has a dual effect. On the one hand, the decrease in labor force is reducing agricultural output and hence food availability. On the other hand, several women noted that the remittances they received from their migrating men mitigated any negative impacts (Thieme \& Wyss, 2005). While a female headed household may be more exposed to external violence, women in Rolpa did not report an increase in insecurity. This could be explained by the generally low crime levels and strong social bonds within and between mountain villages.

While we found little indication that migration leads to more communal violence in the sending areas, the conflict potential can increase in the receiving area, especially if the migration is internal, forced and large-scale. Respondents reported of cases in the Bageshowri VDC in Banke, which is a largely resettled VDC made up of people from Surket and Dailekh. Although the Madeshi population form the majority in this area, the migrant incomers were Pahadi people from the hills. Respondents claimed that because of government sponsored resettlement, the caste and ethnic composition of the receiving community was altered which in turn promoted discrimination against the incomers. According to respondents, Madeshi people felt that the incomers were putting increased pressure on resources, not just on water and land, but also on development projects, such as road infrastructure. While there are reports supporting the existence of conflicts related to Medeshi migrationin Banke (IRIN, 2007; Miklian, 2008), we were unable to find scientific studies to support the claims of our respondents. This was not the case for statements made by the respondents on resource conflicts unrelated to migration (see for example Upreti, 2004). In Banke, several respondents noted conflicts between neighboring farms over the use of groundwater resources. The conflicts were reported to revolve around deep drilling as each borehole affects the amount of groundwater left for other community members. Due to a lack of government monitoring of borehole drilling, disputes are resolved within the community. The drilling of boreholes requires the use of heavy and expensive machinery, which only the wealthiest in the community can afford. It is hence likely that increased water scarcity widens the wealth gap between richer and poorer community members.

In Pakistan, we identified several ways in which environmental change contributes to existing conflicts. The conflicts can broadly be classified into conflicts over land and over fish resources (Table 4). According to several farmers and other community members, the higher rainfall variability and frequency of floods as well as prolonged droughts have contributed to a decrease in vegetation cover and pasture. The pasture is mostly owned by wealthier landlords or influential tribes. Land previously used for grazing has either been diverted by landlords to agricultural use or has become degraded due to lack of water or sea water intrusion. In rural communities, where livestock is an important source of earning, income from livestock has been reported as declining. During the summer, people from the water deficient Thar area mostly come to Badin to graze their animals. This traditional movement has recently been altered. Because of limited vegetation cover, the natives of Badin no longer allow Thari livestock to graze on their land. According to community respondents from Badin, these conflicts are affecting their income and weakening the status of the local communities.

Conflicts over land and fish resources can be connected as a loss of fertile agricultural land has compelled communities to change their profession from agriculture to fisheries. This has resulted in the overharvesting of fisheries and decline in fish populations. Respondents from the Jatt community, traditionally involved in 
agriculture and livestock, explained that they have been forced to take up fishing as their prime profession. The Jatt compete increasingly with local fishermen for fish. Local fishermen accused the Jatt of using illegal nests (locally called Katra or Gujo) with very low mesh sizes. As these nets catch very small and juvenile fish, the fish population loses its ability to recover. These conflicts can be aggravated by climatic changes indirectly through effects on agriculture and directly through decreased water levels. For example, lower water levels of the Indus river decrease the discharge into its delta region which is a breeding ground for fish and other marine life (Memon et al., 2011).

\section{Synthesis of Results}

The aims of this study were (a) to analyze community vulnerability in Nepal and Pakistan to environmental risks, and (b) to show how these risks affect the resilience of the local communities. Figure 4 provides an overview of the main results and how they are connected. The center column summarizes the vulnerability (section 3.1) and the right one the effects on community resilience (3.2). On the left, government adaptation measures are shown and how they are linked to vulnerability. A plus symbol indicates an increasing effect while a minus refers to the opposite. For instance, environmental exposure in the form of floods and landslides is likely to increase the reduction of resources (hence a positive connection). Connections identified for Pakistan are shown with orange arrows. Red arrows refer to Nepal, while black arrows indicate that this connection is supported by findings in both studies. The study areas in both countries are exposed to different environmental risks. In both countries, the unpredictability of the climate and especially the intra and inter-annual rainfall variability were of major concern for the respondents. In Nepal, the specific risks associated with rainfall were floods, landslides and droughts in addition to forest fires during the dry season. In Pakistan, the risks included floods, storms and droughts (Figure 4). The findings of the qualitative research are supported by the analysis of the secondary data and literature analysis. While the sensitivity to the environmental risks was not the main focus of this paper, our study suggests a high sensitivity in all research regions as the majority of people depend on water and land resources for their livelihoods. The analysis of adaptive capacity in Nepal and Pakistan identified three central obstacles to adaptation, three partly successful adaptation measures as well as two cases of mal-adaptation. In both countries poor governance was found to be an obstacle for adaptation. In Nepal, this was mainly related to the perceived disconnect between local communities and governmental institutions. In Pakistan, distribution of land and land access based on political affiliation as well as the Left Bank Outfall Drain (LBOD) and Right Bank Outfall Drain (RBOD) projects have undermined the relations between local communities and government representatives. Other obstacles to adaptation included, limited foresight (in Nepal related to past civil war) and a general lack of jobs, education and infrastructure. In parts, these obstacles were addressed by the Local Governance and Community Development Programme and the Feed the Future program in Nepal and the Watan card program to compensate for flood losses in Pakistan (summarized under poverty reduction programs/disaster compensation in Figure 4). While none of these programs were without externalities, their negative consequences were not as significant as the ones caused by the government-led provision of rice in Nepal and the LBOD/RBOD project in Pakistan. In the short run, the provision of rice increases food security and decreases the community's dependence on agriculture. In the long run however, the provision of rice decreases the incentive for communities to adapt to environmental changes (Figure 4). It further creates a general demand for rice, which undermines the production of tradition, more sustainable crops. In Pakistan, the LBOD/RBOD project has mainly increased the exposure of communities to floods as indicated by the respondents and the secondary reports. Effects of environmental changes on community resilience included reduction of resources, migration and conflicts over water in Nepal and conflict over land and fish resources in Pakistan (Figure 4).

The figure further illustrates that government adaptation measures influence all three elements of vulnerability, both positively and negatively. The right part of the figure shows that the link between a reduction of resources and an increased conflict potential is more direct in Pakistan while in Nepal it is partly catalyzed through mitigation as indicated by the respondents. In both countries however, conflict can be seen as an outcome of and contributing factor to vulnerability. This finding is likely to be relevant for other regions facing conflict and environmental risks such as parts of Africa (Neil Adger \& Mick Kelly, 2005; Schilling, 2012) 


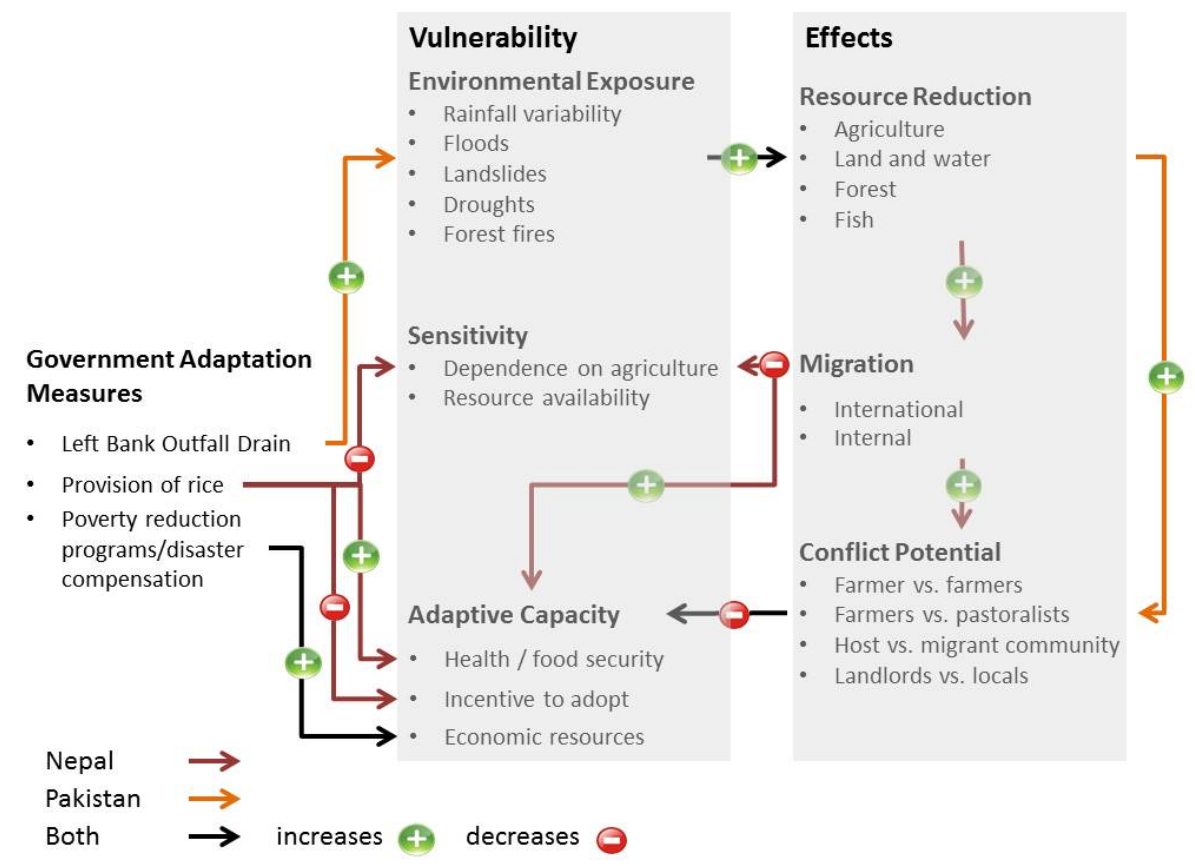

Figure 4. Schematic overview of key interactions between adaptation measures, vulnerability and effects (the authors)

\section{Conclusions}

The high environmental exposure, likely to increase due to climate change, creates a strong need for improved resilience and adaptive capacities among rural communities. However, any government-led adaptation measure needs to be accompanied by a careful assessment of the potential unintended negative effects of the measure. This is especially important for larger infrastructure projects that can increase the exposure to environmental risks as seen in the case of the LBOD/RBOD project. Financial compensation for disaster related losses are promising as they directly strengthen the community's economic adaptive capacity. However, these measures need to be developed, coordinated and implemented in ways which reduce local income disparities and the potential for corruption. The communities' negative perception of their government institutions is a general challenge for adaptation as it decreases the likelihood of local communities being supportive of any adaptation measures initiated by the government. The disconnect between the communities and the government further increases the risk of conflict (Brinkerhoff, 2011) which in turn weakens local resilience. Hence, measures are promising which give opportunity for interaction with political representatives, encourage political engagement and strengthen the social contract. This finding is relevant beyond our case studies as "such a viable social contract can be sufficient to restrain, if not eliminate, opportunistic behavior such as large-scale theft of resource rents, and the violent expression of grievance" (Murshed \& Tadjoeddin, 2009). In Banke, for example, a stronger government regulation of borehole drilling could help to mitigate conflicts between farmers. Overall, the study shows that the communities face multiple environmental risks in combination with political challenges. This stresses the need for further research and governmental policies that understand vulnerability to environmental risks, governance and conflict as interconnected phenomena.

\section{Acknowledgments}

We thank all respondents for their generous contributions of time, energy and insight. We thank Dan Smith, Phil Vernon, Rabia Nusrat, Emily Speers Mears, Fawad Khan, Mandana Hendessi, Bishnu Upreti and Dominic de Ville for invaluable feedback and comments. We thank Rinchen Lama and Sora Chung for background research assistance. In addition, the report also benefited from the support of International Alert's Nepal programme team. We thank the three anonymous reviewers and the editor for their helpful comments.

The paper is a result of the collaboration with the South Asia Network on Security and Climate change (SANSaC). The paper is also part of United States Agency for International Development (USAID) and International Alert's ongoing work to better understand the dimensions of community resilience in South Asia.

International Alert is grateful for the support from our strategic donors: the UK Department for International 
Development (DFID) and the support of the American People through the United States Agency for International Development (USAID).

\section{References}

Adger, W. N. (2006). Vulnerability. Global Environmental Change, 16(3), 268-281. http://dx.doi.org/10.1016/j.gloenvcha.2006.02.006

Allison, E. H., Perry, A. L., Badjeck, M. C., Adger, W. N., Brown, K., Conway, D., ... Dulvy, N. K. (2009). Vulnerability of national economies to the impacts of climate change on fisheries. Fish and Fisheries, 10(2), 173-196. http://dx.doi.org/10.1111/j.1467-2979.2008.00310.x

Arby, M. F., \& Rasheed, M. A. (2010). Estimating gross provincial accounts of Sindh. Pakistan Business Review $10,539-587$

Barnett, J., \& Adger, W. N. (2007). Climate change, human security and violent conflict. Political Geography, 26, 639-655. http://dx.doi.org/10.1016/j.polgeo.2007.03.003

Barnett, J., \& O’Neill, S. (2010). Maladaptation. Global Environmental Change, 20(2), 211-213. http://dx.doi.org/10.1016/j.gloenvcha.2009.11.004

Beg, M. A. (2012). Climate change and socioeconomic problems: A case of Pakistan. In M. A. Khan, \& S. S. Shaukat (Eds.), Security implications of climate change in south Asian countries-proceedings of higher education commission (pp. 18-31). Karachi: Institute of Environmental Studies University of Karachi.

Bogner, A., Littig, B., \& Menz, W. (Eds.) (2009). Interviewing experts. London: Palgrave Macmillan. http://dx.doi.org/10.1057/9780230244276

Brinkerhoff, D. W. (2011). State fragility and governance: Conflict mitigation and subnational perspectives. Development Policy Review, 29(2), 131-153. http://dx.doi.org/10.1111/j.1467-7679.2011.00529.x

Brooks, N., Adger, W. N., \& Kelly, P. M. (2005). The determinants of vulnerability and adaptive capacity at the national level and the implications for adaptation. Global Environmental Change Part A, 15(2), 151-163 http://dx.doi.org/10.1016/j.gloenvcha.2004.12.006

Channa, A. (2011). Abandoned rbod poses danger to Dadu, Jamshoro. Retrieved 25 April, 2013, from http://www.pakistantoday.com.pk/2011/09/14/city/karachi/abandoned-rbod-poses-danger-to-dadu-jamshoro/

CIA. (2013a). The world factbook - Nepal. Retrieved 12 April, 2013, from https://www.cia.gov/library/publications/the-world-factbook/geos/np.html

CIA. (2013b). The world factbook - Pakistan. Retrieved 12 April, 2013, from https://www.cia.gov/library/publications/the-world-factbook/geos/pk.html

CRED. (2013). In Country profile. Retrieved 15 April, 2013, from http://www.emdat.be/country-profile

Daily Times. (2012). Watan cards distribution: Sindh govt yet to start second phase. Retrieved 17 April, 2013, from http://www.dailytimes.com.pk/default.asp?page=2012\%5C03\%5C08\%5Cstory_8-3-2012_pg12_5

DDMA. (2011). Disaster contingency plan 2011 - district Thatta. Retrieved 16 April, 2013, from http://pdma.pk/pd/thatta/Thatta.pdf

del Rio, S., Iqbal, M. A., Cano-Ortiz, A., Herrero, L., Hassan A., \& Penas, A. (2013). Recent mean temperature trends in Pakistan and links with teleconnection patterns. International Journal of Climatology, 33(2), 277-290. http://dx.doi.org/10.1002/joc.3423

Dharejo, S. (2012). Fate unknown: Sindh's lakes in danger. Retrieved 25 April, 2013, from http://www.newslinemagazine.com/2012/08/fate-unknown-sindhs-lakes-in-danger/

Do, Q.-T., \& Iyer, L. (2010). Geography, poverty and conflict in Nepal. Journal of Peace Research, 47(6), 735-748. http://dx.doi.org/10.1177/0022343310386175

Duit, A., Galaz, V., Eckerberg, K., \& Ebbesson, J. (2010). Governance, complexity, and resilience. Global Environmental Change, 20(3), 363-368. http://dx.doi.org/10.1016/j.gloenvcha.2010.04.006

Evan, A. T., \& Camargo, S. J. (2011). A climatology of Arabian sea cyclonic storms. Journal of Climate, 24(1), 140-158. http://dx.doi.org/10.1175/2010JCLI3611.1

Feyyaz, M. (2011). Ethnic conflict in Sindh. Islamabat, Pakistan Institute of Legislative Development and Transparency.

Folke, C. (2006). Resilience: The emergence of a perspective for social-ecological systems analyses. Global 
Environmental Change, 16(3), 253-267. http://dx.doi.org/10.1016/j.gloenvcha.2006.04.002

Folke, C., Carpenter, S., Walker, B., Scheffer, M., Chapin, T., \& Rockstrom, J. (2010). Resilience thinking: Integrating resilience, adaptability, and transformability. Ecology and Society, 15(4), 20.

Füssel, H.-M. (2007). Vulnerability: A generally applicable conceptual framework for climate change research. Global Environmental Change, 17(2), 155-167. http://dx.doi.org/10.1016/j.gloenvcha.2006.05.002

Gallopín, G. C. (2006). Linkages between vulnerability, resilience, and adaptive capacity. Global Environmental Change, 16(3), 293-303. http://dx.doi.org/10.1016/j.gloenvcha.2006.02.004

Galvin, J. (2007). Severe tropical storm over India and south-west Asia. Weather, 62(12), 337-338. http://dx.doi.org/10.1002/wea.149

Global Adaptation Institute. (2011). Country rankings. Retrieved 17 April, 2013, from $\mathrm{http} / / /$ index.gain.org/ranking/vulnerability

Government of Nepal. (2006). About lgcdp. Retrieved 17 April, 2013, from http://www.lgcdp.gov.np/home/about_lgcdp.php\#1

Government of Nepal. (2011). Climate change policy 2011. Retrieved 17 April, 2013, from $\mathrm{http} / / / \mathrm{www} . c$ limatenepal.org.np/main/? $\mathrm{p}=$ research\&sp=onlinelibrary\&opt=detail\&id=419

Government of Pakistan. (2007). National disaster risk management framework Pakistan. Islamabad, Government of Pakistan.

Government of Sindh. (2008). Badin. Retrieved 17 April, 2013, from http://www.pwdsindh.gov.pk/districts/badin.htm

Government of the United States. (2006). U.S. position on the World Bank's inspection panel report on the national drainage program project for Pakistan. Retrieved 17 April, 2013, from http://www.treasury.gov/resource-center/international/development-banks/Documents/10.31.2006\%20U.S. \%20Position\%20on\%20the\%20World\%20Bank\%E2\%80\%99s\%20Inspection\%20Panel\%20Report\%20on $\% 20$ the $\% 20$ National\%20Drainage\%20Program\%20Project\%20for\%20Pakistan.pdf

Inter-Agency Working Group on Resilience. (2012). The characteristics of resilience building. Retrieved 2 April, 2013, from http://community.eldis.org/?233@@.5ad4406d!enclosure=.5ad4406e\&ad=1

International Bank for Reconstruction and Development. (2006). Management report and recommendation in response to the inspection panel investigation report. Retrieved 17 April, 2013, from http://siteresources.worldbank.org/EXTINSPECTIONPANEL/Resources/MgmntRprt\&Recommendatiomin RspnsetoPanelInvestigationRprt.pdf

IPCC. (2007a). Climate change 2007. Climate change impacts, adaptation and vulnerability. Geneva: Cambridge University Press.

IPCC. (2007b). Climate change 2007: Synthesis report. Contribution of working groups I, II and III to the fourth assessment report of the intergovernmental panel on climate change. Geneva, IPCC.

IRIN. (2007). Nepal-Maoists and Madhesi activists clash in Terai. Retrieved 13 June, 2013, from http://www.irinnews.org/report/70464/nepal-maoists-and-madhesi-activists-clash-in-terai

IRIN. (2009). Nepall: Floods, landslides hit food stocks. Retrieved 13 April, 2013, from http://www.irinnews.org/Report/86692/NEPAL-Floods-landslides-hit-food-stocks

Junejo, J. (2011). Revisiting the lbod issue. Retrieved 22 April, 2013, from http://dawn.com/2011/10/06/revisiting-the-lbod-issue/

Kale, V. (2012). On the link between extreme floods and excess monsoon epochs in South Asia. Climate Dynamics, 39(5), 1107-1122. http://dx.doi.org/10.1007/s00382-011-1251-6

Kripalani, R. H., Oh, J. H., Kulkarni, A., Sabade, S. S., \& Chaudhari, H. S. (2007). South Asian summer monsoon precipitation variability: Coupled climate model simulations and projections under ipcc ar4. Theoretical and Applied Climatology, 90(3-4), 133-159. http://dx.doi.org/10.1007/s00704-006-0282-0

Kurosaki, T., Khan, H., Shah, M. K., \& Tahir, M. (2012). Household-level recovery after floods in a developing country: Further evidence from Khyber Pakhtunkhwa, Pakistan. Retrieved 17 April, 2013, from http://www.ier.hit-u.ac.jp/primced/documents/No27-dp_up_Pdf_2012_002.pdf

Memon, J. A., \& Thapa, G. B. (2011). The Indus irrigation system, natural resources and community 
occupational quality in the delta region of Pakistan. Environ Manage, 47(2), 173-187. http://dx.doi.org/10.1007/s00267-010-9569-0

Miklian, J. (2008). Nepal's terai: Constructing an ethnic conflict. Retrieved 25 April, 2013, from http://www.ashraya-nepal.com/documents/Nepals_Terai_(South_Asia_Briefing_Paper_1).pdf

Ministry of Environment. (2010). Climate change vulnerability mapping for Nepal. Retrieved 16 April, 2013, from

http://www.napanepal.gov.np/pdf reports/CLIMATE\%20CHANGE\%20VULNERABILITY\%20MAPPIN G\%20FOR\%20NEPAL\%20INNER.pdf

Murshed, S. M., \& Tadjoeddin, M. Z. (2009). Revisiting the greed and grievance explanations for violent internal conflict. Journal of International Development, 21(1), 87-111. http://dx.doi.org/10.1002/jid.1478

National Institute of Population Studies. (2008). Pakistan demographic and health survey 2006-07. Islamabad: National Institute of Population Studies.

Nelson, M. J. (2012). Mohajir militancy in Pakistan: Violence and transformation in the Karachi conflict. Pacific Affairs, 85(1), 227-229.

Pakistan Today. (2012). Lo and behold! 2nd watan card tranche only for 260,000. Retrieved 17 April, 2013, from http://www.pakistantoday.com.pk/2012/01/29/city/karachi/lo-and-behold-2nd-watan-card-tranche-only-for260000/

Patton, M. Q. (2005). Qualitative research. Encyclopedia of statistics in behavioral science. John Wiley \& Sons, Ltd. http://dx.doi.org/10.1002/0470013192.bsa514

Paul, T. (Ed). (2005). The India-Pakistan conflict. Cambridge: Cambridge Univeristy Press. http://dx.doi.org/10.1017/CBO9780511616112

Polsky, C., Neff, R., \& Yarnal, B. (2007). Building comparable global change vulnerability assessments: The vulnerability scoping diagram. Global Environmental Change, 17(3-4), 472-485. http://dx.doi.org/10.1016/j.gloenvcha.2007.01.005

Pope, J., Annandale, D., \& Morrison-Saunders, A. (2004). Conceptualising sustainability assessment. Environmental Impact Assessment Review, 24(6), 595-616. http://dx.doi.org/10.1016/j.eiar.2004.03.001

Pradhan, B., Shrestha, S., Shrestha, R., Pradhanang, S., Kayastha, B., \& Pradhan, P. (2013). Assessing climate change and heat stress responses in the tarai region of Nepal. Ind Health, 51(1), 101-112. http://dx.doi.org/10.2486/indhealth.2012-0166

Sarfaraz, S., \& Dube, S. K. (2012). Numerical simulation of storm surges associated with severe cyclones land falling pakistan coast during 1999-2010. Pakistan Journal of Meteorology, 8(16), 11-20

Scheffran, J., Link, P. M., \& Schilling, J. (2012). Theories and models of climate-security interaction: Framework and application to a climate hot spot in North Africa. In J. Scheffran, M. Brzoska, H. G. Brauch, P. M. Link, \& J. Schilling (Eds.), Climate change, human security and violent conflict: Challenges for societal stability (Vol. 8, pp. 91-131). Berlin: Springer. http://dx.doi.org/10.1007/978-3-642-28626-1_5

Schilling, J. (2012). On rains, raids and relations: A multimethod approach to climate change, vulnerability, adaptation and violent conflict in northern Africa and Kenya. Hamburg: University of Hamburg.

Schilling, J., Freier, K. P., Hertig, E., \& Scheffran, J. (2012). Climate change, vulnerability and adaptation in North Africa with focus on Morocco. Agriculture, Ecosystems \& Environment, 156, 12-26. http://dx.doi.org/10.1016/j.agee.2012.04.021

Sharma, K. (2006). The political economy of civil war in Nepal. World Development, 34(7), 1237-1253. http://dx.doi.org/10.1016/j.worlddev.2005.12.001

Shrestha, A. B., \& Aryal, R. (2011). Climate change in Nepal and its impact on Himalayan glaciers. Regional Environmental Change, 11(1), 65-77. http://dx.doi.org/10.1007/s10113-010-0174-9

Shrestha, A. B., Eriksson, M., Mool, P., Ghimire, P., Mishra, B., \& Khanal, N. R. (2010). Glacial lake outburst flood risk assessment of sun Koshi basin, Nepal. Geomatics Natural Hazards \& Risk, 1(2), 157-169. http://dx.doi.org/10.1080/19475701003668968

Siddiqui, Z. A. (2009). Storm surge forecasting for the Arabian Sea. Marine Geodesy, 32(2), 199-217. http://dx.doi.org/10.1080/01490410902869524 
Smit, B., \& Wandel, J. (2006). Adaptation, adaptive capacity and vulnerability. Global Environmental Change, 16(3), 282-292. http://dx.doi.org/10.1016/j.gloenvcha.2006.03.008

Smith, D. (2004). Towards a strategic framework for peacebuilding - getting their act together. Oslo: Royal Norwegian Ministry of Foreign Affairs.

Thieme, S., \& Wyss, S. (2005). Migration patterns and remittance transfer in Nepal: A case study of Sainik Basti in western Nepal. International Migration, 43(5), http://dx.doi.org/10.1111/j.1468-2435.2005.00342.x

Transparency International. (2012). Corruption perceptions index 2012. Retrieved 17 January, 2011, from http://www.transparency.org/cpi2012/results

UN. (2011). World population prospects-the 2010 revision. New York: United Nations.

UNFCO. (2011). An overview of the mid western region of Nepal. Retrieved 16 April, 2013, from http://www.internal-displacement.org/8025708F004CE90B/(httpDocuments)/63E8E9319C5A3C70C12579 80002F7183/\$file/Nepal_Mid_Western_Region_Overview_Paper_0.pdf

UNOCHA. (2010). Pakistan floods 2010-thatta district profile. Retrieved 16 April, 2013, from www.pakresponse.info

UNOSAT. (2010). Pakistan-floods 2010 extent. Retrieved 1 May, 2013, from http://www.pakresponse.info/MapDataCenter/GISData.aspx

Upreti, B. R. (2004). Resource conflicts and conflict resolution in Nepal. Mountain Research and Development, 24(1), 60-66. http://dx.doi.org/10.1659/0276-4741(2004)024\%5B0060:RCACRI\%5D2.0.CO;2

Wang, B., Ding, Q., Fu, X., Kang, I.-S., Jin, K., Shukla, J., \& Doblas-Reyes, F. (2005). Fundamental challenge in simulation and prediction of summer monsoon rainfall. Geophys. Res. Lett., 32(15), L15711. http://dx.doi.org/10.1029/2005GL022734

Weaver, A., Pope, J., Morrison-Saunders, A., \& Lochner, P. (2008). Contributing to sustainability as an environmental impact assessment practitioner. Impact Assessment and Project Appraisal, 26(2), 91-98. http://dx.doi.org/10.3152/146155108X316423

WFP. (2010a). Crop situation update. Retrieved 17 April, 2013, from http://wfp.nepasoft.com.np/nefoodsec/Crop\%20Situation\%20Update/CropSituationUpdate_issue10English. pdf

WFP. (2010b) Food security bulletin. Retrieved 17 April, 2013, from http://wfp.nepasoft.com.np/nefoodsec/Food\%20Sec\%20Bulletin/Eng/Food\%20Security\%20Bulletin_Issue $\% 2010 . p d f$

Wheeler, D. (2011). Quantifying vulnerability to climate change: Implications for adaptation assistance. Retrieved $\quad 10 \quad$ June, 2013, from http://international.cgdev.org/publication/quantifying-vulnerability-climate-change-implications-adaptationassistance-working

World Bank. (1997). Left Bank Outfall Drain project tackling Pakistan's waterlogging and salinity problems. Retrieved $17 \quad$ April, $2013, \quad$ from http://web.worldbank.org/WBSITE/EXTERNAL/PROJECTS/0,,contentMDK:20017537 menuPK:642821 37 pagePK:41367 piPK:279616 theSitePK:40941,00.html

World Bank. (2010). World development indicators 2010. Retrieved 20 May, 2010, from http://data.worldbank.org/data-catalog

World Bank. (2013). World development indicators. Retrieved 12 February, 2013, from http://data.worldbank.org/data-catalog/world-development-indicators

Wu, S. S., Yao, Z. J., Huang, H. Q., Liu, Z. F., \& Liu, G. H. (2012). Responses of glaciers and glacial lakes to climate variation between 1975 and 2005 in the Rongxer basin of Tibet, China and Nepal. Regional Environmental Change, 12(4), 887-898. http://dx.doi.org/10.1007/s10113-012-0302-9

\section{Notes}

Note 1 . The vulnerability indices in the NAPA do not look at political or conflict risks. The assessments are based on environmental risks and a range of socio-economic factors such as population density and 
infrastructure.

Note 2. The flood category includes general river floods, flash floods and coastal floods (CRED, 2013).

Note 3. The five POs include Taraqee Trust, Quetta (Balochistan); the Agha Khan Rural Support Programme (AKRSP), Gilgit (Northern Areas); the National Rural Support Organisation (NRSP), Islamabad (Federal Area); the Family Planning Association of Pakistan (FPAP), Lahore (Punjab); and the Kashf Foundation, Lahore (Punjab).

Note 4. For a general overview of sustainability assessments see Pope, Annandale \& Morrison-Saunders (2004) and Weaver, Pope, Morrison-Saunders \& Lochner (2008).

\section{Copyrights}

Copyright for this article is retained by the author(s), with first publication rights granted to the journal.

This is an open-access article distributed under the terms and conditions of the Creative Commons Attribution license (http://creativecommons.org/licenses/by/3.0/). 